\title{
Diagnosing a case of venereal disease in fifteenth century Scotland
}

\author{
ELLIS HERNDON HUDSON
}

Laguna Hills, California

My attention was first drawn to Robert Henryson, the Scottish poet, by Roger Green (1964): 'It reminds me of Henryson's movingly cruel version of the story of Criseyde. A lovely woman begins by deceiving one man with another, continues by turning prostitute and ends, her beauty squandered and ugliness in its place, as a leper with a bell and a begging bowl'.

In The Testament of Cresseid the poet Henryson portrayed a prostitute who acquired an incurable sickness'. According to conventional medical history today, her disease could not have been syphilis because she was a literary creation of the fifteenth century, supposedly before syphilis appeared in Europe. Those who adhere to tradition explain Cresseid's sexually acquired infection by invoking the medieval diagnosis of 'venereal leprosy'.

The clinical and epidemiological features of her case, however, as Henryson gives them and as they are analysed herein, seriously challenge this view. On the contrary, the unfolding story leaves little doubt that it was syphilis which Cresseid the prostitute acquired, and not some kind of leprosy.

Thus another piece of evidence is in hand to support the newer and less widely held view that syphilis was indeed present in Scotland (and if in Scotland, doubtless in the rest of Europe) before the closing years of the fifteenth century.

\section{THE STORY}

The tale of the Trojan lovers can be traced from early European literature through Boccaccio and Chaucer in the fourteenth century, Henryson in the fifteenth, and Shakespeare (Troilus and Cressida) in the sixteenth.

The simple plot is laid in the classic time of the Trojan War. Troilus, a flawless knight, younger brother of Hector, is in love with Cresseid, a paragon of beauty and grace. Suddenly, Cresseid is snatched

Received for publication October 8, 1971

Address: E. H. Hudson, M.D., F.A.C.P., 745-C Avenida Majorca, Laguna Hills, California 92653, U.S.A. away by order of Priam, to be sent to the Greeks as ransom for a captured warrior. Troilus gives her his ruby ring and Cresseid promises fidelity; but she is beguiled by her new life among the Greeks on the Aegean shore. Forgetting her vow to Troilus, she gives herself to her new master, Diomeid, and when he discards her, she becomes a prostitute in the Greek encampment.

CHAUCER (1340-1400) AND HENRYSON (1440?-1500?)

Robert Henryson admired and often echoed his English predecessor; he composed his best poem, The Testament of Cresseid, in Chaucerian rhyme royal and admitted that it was intended to be a sequel to Chaucer's Troilus and Criseyde. So successful was this attempt that the Testament for many years was bound with Chaucer's works, and Henryson almost lost the credit for it.

Yet there were striking differences between the two poets in their handling of the narrative. The Chaucerian version ended with Troilus dead in combat and Cresseid surviving as a wretched beggar. Henryson, however, gave the story a dramatic twist, leaving the chaste Troilus sad but alive, while Cresseid, a devotee of Venus, goddess of 'fleshly love', blasphemed against the gods, was cursed with an incurable disease, and at last died a 'leper'.

The two poets displayed further contrast in their attitudes toward the morals of sexual love. On the one hand, Chaucer in the fourteenth century was still influenced by the twelfth century court of Eleanor of Aquitaine, characterized both by relaxed morals and chivalric idealism. On the other hand, Henryson in the fifteenth century rejected this socalled 'courtly love', choosing rather to describe the sexual relation as fleshly love in antithesis to spiritual love. It was assumed in what was then Catholic Scotland that transgression, particularly sexual, would be followed by condign punishment. There was a sternness in the Scottish character that demanded appropriate retribution for every $\sin$. It was not just a historical coincidence that Knox and 
Calvin, contemporaries in the sixteenth century, were waiting in the wings, Knox with his Reformation and Calvin with his Predestination.

Although Henryson was sensitive to the spirit of his time, it is a measure of his genius that, while conforming to orthodox moral standards and condemning promiscuous Cresseid, he nevertheless retained for himself and for the reader a lively sense of pity for the erring woman. Consequently, both poet and reader can sympathize in her final humiliation, submission, testament, and death, as they see her performing her earthly penance, thus escaping her purgatory and passing directly to heaven.

\section{POEM AND POET}

The Testament, consisting of 616 lines divided into 86 stanzas, has been described as perhaps the finest poem ever written by a Scot. Both the original and all contemporary copies were handwritten and none survives. Present texts are largely based on a version included in Chaucer's works printed in England in 1532, and another printed singly in Edinburgh in 1593, a full century after the poem was written. The precise year of its composition is not known, but the information that follows is pertinent.

The Asloan Manuscript is a collection which touches upon the Testament at two points (Craigie, 1923-25). In the first place, the index lists The Testament of Cresseid, though it was in a portion of the MS that has been lost. Secondly, a prose treatise in the extant part of the Asloan MS, entitled The Spektakle of Luf, gives a more definite lead. It was written by a certain G. Myll whose declared purpose was to warn men against 'the delectation of love'. To illustrate his argument, he listed Cresseid along with other notorious women of history. Myll not only gave the Henryson version but repeated actual words and phrases of the Testament.

Thus the evidence clearly points to the conclusion that Henryson's poem was in circulation in Scotland when Myll finished his anti-feminist tract. Fortunately, he signed and dated his composition in his own hand at the end. The date was $10 \mathrm{July}$, 1492 !

Details of Henryson's life are lacking and even his dates are in doubt, but he is believed to have been a schoolmaster, and perhaps a notary, in the small Fifeshire town of Dunfermline. There Henryson lived when he produced his poems, the greatest of the Scottish makars (poets). He wrote in the dialect of his own land and time (Middle Scots), revealing wide knowledge of astrology, mythology, and the professions of medicine, law, and the church.

\section{Cresseid's Testament: Outline and Paraphrase*}

Betrayals

Henryson takes up the story at the point, "Quhen [when] Diomeid had all his appetyte, and mair, fulfillit of this fair ladie"'. Thus repudiated, Cresseid wandered promiscuously among the Greeks, falling to the low estate of a prostitute. Here Henryson, using the Chaucerian device of a Narrator, breaks into the following lament:

\section{' $O$ fair Cresseid, the flower and A per se [first] Of Troy and Greece, how wast thou unfortunate To change into filth all thy feminity, And be with fleshly lust so maculate [spotted], And go among the Greeks early and late, So strumpet-like, taking thy foul pleasure! I have pity thou shouldst fall into such mischance!'}

As the poem proceeds it is plain that Henryson attuned his poetry in many respects to his Scottish audience. Like the Old Masters who painted their biblical scenes in European landscapes and peopled them with peasants in contemporary garb, Henryson wove into the narrative many of the details of life in his fifteenth century Scotland. The Greek tents on the shore have changed into a built-up town on whose streets the courtesan Cresseid 'walked to and fro'. The primitive Greek shrine to Venus has become a handsome structure, called a 'kirk', complete with oratory and served by a priest, Calchas, whom Henryson names as Cresseid's own father.

When Cresseid had suffered scorn and degradation beyond endurance, she sought refuge with her father. It was a 'Holy Day and devout folk were coming to the kirk from far and near before noon, as was the custom, to worship and sacrifice'. It was in keeping with this picture of the Sunday morning mass that Cresseid came in disguise and entered a side chapel to escape the congregation and avoid their gossip about her rejection by Diomeid.

Closing the door, she kneeled weeping, angrily upbraiding Venus and her son Cupid for breaking their promise that she should be 'the flower of love in Troy':
'Alas, that ever I made thee a sacrifice! . . .
Now am I made an unworthy outcast,
And all into sorrow translated is my joy. ... .
$O$ false Cupid, no one is to blame but thou
And thy mother, the blind goddess of love.'

This arrogant blasphemy so incensed Venus that she bade Cupid-as Cresseid swooned-to call a council of the gods (planets) to hear her indignation

\footnotetext{
*The single quotation mark is employed to indicate a modernized spelling or a paraphase of the text. The double mark signifies, as usual, an exact quotation.
} 
against this 'unclean and lecherous woman' and determine the penalty to be imposed.

\section{Fudgment of the Gods}

At Cupid's summons, six gods descended from their spheres, Saturn first, then Jupiter, Mars, and Mercury in turn, followed by Phoebus, the sun, and Cynthia, the moon. Since this insolent mortal had offended not one but all the gods, there was no question of her guilt; it was only necessary to prescribe the appropriate punishment. Saturn and Cynthia, both of them symbols of disease and melancholy, were nominated to pronounce the sentence, a fitting one indeed for a prostitute.

Henryson knew that among his people sickness was often observed to follow venery. Since the microbic mechanism of infection was still a closed book, he also shared the common belief that venereal disease was partly due to divine displeasure when the law of chastity was broken. Indeed, the notion that the origin of sexually acquired diseases is related to a sort of vindictive fate is not altogether dead today. It was easy therefore for the poet to attribute Cresseid's sickness to the wrath of the gods.

First, Saturn, 'cold and dry', laid his 'frosty wand' on her head saying:

'I deprive thee for evermore of thy great fairness and thy gay beauty, and also thy golden hair. I change thy mirth into melancholy, mother of all sorrow; thy moisture and thy heat into cold and dry; thine insolence, thy play and wantonness into great disease; thy pomp and thy richness into mortal need; and thou shalt suffer great poverty and as a beggar die'.

At these dreadful words, the narrator again exclaims:

' $O$ cruel Saturn, this doom is severe and malicious; why hast thou no mercy on fair Cresseid, once so sweet, gentle and loving?'

But Cynthia, cold and vindictive, approached the prostrate Cresseid, saying:

'I take away the warmth of thy body; thy sickness will have no cure and thy days will be full of sorrow. I make thy crystal eyes shot with blood, thy clear voice raucous and thy face overspread with dark spots and livid lumps. All men will flee the place where thou comest. Thou shalt go begging from house to house with cup and clapper like a leper'.

In the Scottish scene, 'lepers' with their warning clappers and their bowls for alms or bread, could be seen daily in the closes and wynds of Edinburgh, or grouped at the entrances of such towns as Dunfermline and Aberdeen.

\section{Curse of Venus}

When Cynthia ceased all the gods vanished and Cresseid awaking reached for a mirror; then she realized Venus had indeed repaid her rash recriminations with a curse-

'to be oppressed for all her life with the pain and sore torment of an incurable disease and to become abominable to all lovers'.

Seeing her ugly reflection she continued in her self-pity to lament the repulsive disease that her blasphemy had bought from the hands of the illnatured ("craibit") gods.

While Cresseid wept in sore despair, a child came to say that supper was ready, but she called for her father. In the poem, Calchas had now been transformed from a servant of Venus into a Scottish parish priest, trained to recognize the signs of 'leprosy' and legally authorized to identify and isolate such cases. Seeing his daughter's disfigured face and knowing what her fate was to be, he joined her in quiet mourning. At last, she asked him to take her to the "spitall", the refuge outside the town where such as she were required to lodge. Historically, there was such a refuge outside Dunfermline, perhaps in Nethertown, a village that still exists.

Calchas thereupon gathered up some food, put on his 'cloak and beaver hat', symbols of dignity and authority, and led her by a secret gate under cover of darkness to the nearby village. There Cresseid discovered her bed of straw and the mouldy bread, the plate of rancid pork or spoiled salmon, the cup of small beer or sour cider, the customary diet of 'lepers in lazarhouses'.

\section{Complaint}

In seven special stanzas, the rebellious woman recalled, amid these sordid surroundings, her past life of luxury and sensual delights, bewailing the 'turn of fortune's wheel'. As she enumerated the many items, the reader would perceive that these were not the belongings of a Trojan maiden, but the trappings of a courtesan in the wealthy and aristocratic circles of the Scottish capital city:

'The chamber voluptuously furnished, the handsome bed, spread with embroidered tapestries, the wellseasoned foods, sweetmeats, spiced wines in silver cups, gay gowns of costly materials pinned with golden brooches, the late suppers and revels with men of wealth and rank; with songs, gardens, flowers, and singing birds'.

Henryson could assume that such things would be popularly supposed to accompany the sybaritic life of a high-class prostitute in fashionable Edinburgh.

\section{The Confrontation}

Finally, broken in spirit, Cresseid accepted her fate, took the cup and clappers, and joined her fellow out- 
casts. One day as they were gathered at the roadsids, a troop of soldiers from the 'Trojan garrison', returning from an 'encounter with the Greeks', caused the beggars hastily to converge with hands outstretched. It happened that their captain was young Troilus, but neither he nor Cresseid recognized the other. However, to the amazement of the beggar folk, he tossed valuable gifts into her lap before passing on. Cresseid, on her part, swooned when she heard that the captain had been Troilus. When she came to herself she cried:
'O false Cresseid and true knight Troilus!
Thy love, thy loyalty and thy gentleness,
I counted small in my prosperity,
So puffed up I was in wantonness,
And climbed upon the fickle wheel so high! . . .
For love of me thou kept continence,
Honest and chaste in conversation. ...
My mind in fleshly foul affection
Was inclined to lecherous lusts.
Fy, O false Cresseid; O true knight Troilus!'

Such bands of beggars and 'lepers' beside the road were a sufficiently familiar sight in Henryson's Scotland for his readers to imagine this dramatic confrontation, the troop of soldiers perhaps from the garrison in Stirling Castle or from the Dunfermline barracks; the fresh-faced captain would be Troilus whose mind for just a moment fused the idyllic memory of a former love with this pitiable creature in the dust, a young man impelled to generous gifts who then rode sadly on as the vision faded.

\section{Testament and Death}

Since Cresseid now realized she was about to die, she undertook her 'testament'. Leaving her cup and clappers and her recent gifts to her companions, and asking that the ruby ring be returned to Troilus, she yielded her body to the grave and wrote: 'I leave my spirit to Diana, to walk with her where she dwells in lonely woods and waters'.

Earlier, when Cresseid was being tried before the council of gods, the poet described the scene in terminology and procedure suggesting a Scottish courtroom. Similarly, when the dying woman wrote her will, she used the conventional legalisms to be expected in such a document, consigning her body to be consumed 'by worms and toads'. According to the usual formula she should then have yielded her spirit to God; but here the poet remembered his classic framework and sent her spirit to join Diana in the sombre mythological afterworld.

\section{The Diagnosis}

CENTRAL FACT

In the words of the Narrator, the Testament was written 'to report the lamentable and woeful end of lustful Cresseid, what distress she endured, and what death'. Henryson, in creating a heroine who abandoned chastity and 'turned to a life of sin', confronted human passion and sexual love with sophistication and without sentimentality. Rejecting euphemisms, he frankly narrated how Cresseid fell into her predicament and how she worked her way out again through suffering, contrition, and forgiveness. At the end, she joined Diana, goddess of chastity, in a celestial setting that doubtless reminded the poet's Catholic readers of the Virgin in Heaven.

The heart of the story, however, was the venereal disease she acquired while a devotee of Venus. This goddess of 'earthly love' was depicted as dressed extravagantly, half in green symbolizing faithlessness, and half in black for misfortune and death. Winking amorously with provocative glances from one eye while weeping from the other, Venus typified the mixture of pleasure and pain, laughter and tears, sweetness and bitterness found in sensual love. Running through the poem is the motif of sexually acquired disease.

\section{WHAT DISEASE?}

Henryson, 500 years ago, called it leprosy. The disease, so acquired, was so designated because at that time there was no other name for it. No one in the field of communicable diseases today, however, would hesitate to say that Cresseid had venereal syphilis. Why then have literary critics not accepted this modern diagnosis? It is because, with one exception (Rowland (1964), who argues that Cresseid had syphilis), they have followed the lead of those medical historians who state that syphilis was not present in pre-Columbian Europe. Having adopted this arbitrary precondition, the dominant writers, medical and lay, would conclude that since Columbus had not yet discovered America, Cresseid could not possibly have had syphilis.

Yet the stubborn fact must be faced that if Cresseid really had leprosy, it was a very different disease from the leprosy of today. How is it possible, then, to account for the following incongruities? Ancient and medieval leprosy was highly contagious, with a short incubation period; it was associated with immorality and sex, transmissible from mother to unborn child, and favourably influenced by mercury treatment.

In contrast, none of these features applies to modern leprosy, one of the least contagious of man's infections, with a prolonged incubation period, sometimes of years, and having no relation either to morals or sexual activity. Modern leprosy is not congenitally transmitted nor does it respond to mercury treatment.

Here is a paradox - a contagious disease, that from a modern viewpoint begs for the diagnosis of venereal 
syphilis, is being attributed to leprosy, a patently incompatible diagnosis. Currently, writers attempt to resolve this paradox by resorting to the general proposition that diseases have been observed to undergo modification in the course of time. Thus, arguing that old leprosy and modern leprosy are the same disease, they account for the obvious discrepancies on the ground that the disease has changed its character (Long, 1964). Modern knowledge of the behaviour of micro-organisms, however, compels the rejection of an explanation involving a metamorphosis so biologically preposterous. Change in the disease itself cannot therefore explain the incongruities between ancient and modern leprosy.

\section{TWO DISEASES}

Fortunately, there is a simpler and much more rational explanation for the manifest differences, which derives from the fact that syphilis, unidentified and unrecognized as such, was completely incorporated within the syndrome of old leprosy which was thus made to comprise two diseases. Like warp and woof, the two strands were so interwoven as to seem to be one disease. In the light of modern diagnostic criteria, however, it is not difficult to disentangle the two strands and identify them as syphilis and true leprosy. Each is now known to be caused by an entirely different agent, leprosy by Mycobacterium leprae, and syphilis (known generically as treponematosis) by Treponema pallidum.

Although each of these diseases pursued its own course, there was confusion when they were lumped together in the diagnosis of 'leprosy'. Some of Cresseid's companions, for example, surely had true leprosy while others, like her, had syphilis. There may be argument today about the proportions of the two diseases in medieval Europe, but there is a strong suspicion that the majority were syphilitic. This is based on the fact that when syphilis was recognized and mercury treatment came into general use, the number of 'lepers' dwindled rapidly.

Looking back at the old leprosy syndrome, it is easy to see why syphilis and leprosy were so long confused. Both were chronic and 'incurable', both produced a skin eruption, laryngitis, ophthalmitis, and alopecia. Both caused ulceration of mouth and nose, sometimes resulting in nasal collapse, a hole in the centre of the face, and ozoena from putrefaction.

Henryson, describing Cresseid's disease, used the terms that were current in the literature of the Middle Ages. She had dark spots and livid lumps on her face, bloodshot eyes, hoarseness, falling hair, and a deformity of the face so terrible that all fled from her. This mixture of signs and symptoms was as confused as the old diagnosis of 'leprosy', from which it derived; it was not specifically characteristic of either syphilis or true leprosy.

\section{ORIGINS}

This close association of leprosy and syphilis may have started in paleolithic times. Since Central Africa is the region of the world where both treponematosis and leprosy occur today in greatest concentration, and since Africa, in the opinion of many anthropologists, was the original home of man, there are grounds for the suggestion that mankind in migrating out of that continent carried these two ancient infections (Hudson, 1963).

Thus treponemal infection, caused by $T$. pallidum, passed through the two epidemiological phases of yaws and endemic syphilis to become venereal syphilis paralleling the social evolution of mankind as it progressed in the course of thousands of years, from hunter to cultivator to civilized man (Hudson, 1965). All this time the specific nature of treponematosis was unrecognized.

\section{SEGREGATION AND STIGMA}

In early historical times, a disease called 'leprosy' appeared in the Middle East. It was still the dual mixture, with the symptoms of syphilis predominating. This old leprosy syndrome, with its open lesions of the skin and genitalia, was associated with shame and immorality. It was believed to be responsible for the bizarre condition called satyriasis, characterized by priapism and excessive sexuality. Sexually-linked 'leprosy' continued through the Dark and Middle Ages, in time acquiring the name 'venereal leprosy'. Prostitutes were regarded as 'leprous'; in London in 1346 an ordinance was enacted to protect people in the public baths from contamination by 'lepers' through 'carnal intercourse'.

It is significant that in the Middle Ages, when diseases were popularly linked with specific sins, leprosy was coupled with lechery. In Henryson's Testament, Cynthia, the moon, wearing her 'spotted gown' (suggesting a skin eruption) and ever changing her shape ('indicative of instability and deceit in earthly love), was pictured as wearing two horns like the extravagant bicornuate headdress affected by women of bad repute.

It is a curious fact of modern leprosy that this old linkage with sex lingers today in the erroneous popular impression that lepers are oversexed.

Segregation of the sick seems to have appeared first in connection with ancient 'leprosy'; it is easy to trace this to the syphilis component of open lesions and short incubation period. It would be obvious, even to primitive people, that new cases came from 
old ones and it would therefore be logical to separate the sick from the healthy. The stigma associated with this ostracism reinforced the shame arising from the aura of sex. It is ironical that the segregation and stigma that derived from syphilis were, in the course of centuries, shifted to true leprosy. As treatment of syphilis improved, fear of it diminished while fear of leprosy remained. Consequently, the victims of modern leprosy, a relatively innocent disease, are forced to bear an irrational burden of stigma and segregation though they constitute no hazard to the public health under modern conditions.

\section{LUES VENEREA}

Until the closing years of the fifteenth century the old syndrome of 'leprosy' in Europe continued to be dominated by its treponemal component. In addition, there were two other areas in which syphilis affected life in the Middle Ages. First, the non-venereal endemic syphilis of childhood was rife among the peasants throughout Europe (Hudson, 1961a).

This condition was also confused with 'leprosy' for centuries and became the syphiloids of the seventeenth and eighteenth centuries. Second, the severe lesions of untreated tertiary syphilis were often given separate names. The huge, purulent, and crusted ulcers were called the 'big scabs', and the wasting disease accompanying deformities and gummata was called the 'deadly sickness' (mort mal) (Hudson, 1961b). About 1500, by a mere change of name, 'venereal leprosy' became the venereal plague (lues venerea) signifying that syphilis was breaking away from its old-time companion and achieving an identity of its own. At the same time, the 'deadly sickness' was seen to be a late stage of lues. Indicating that it was just a change in terminology, medical writers merely changed the titles of their treatises without modifying the contents.

Although many called it a 'new disease', syphilis was simply emerging from the shadow of old 'leprosy' and being newly recognized. Its name in most countries was indigenous and colloquial, as las bubas in Spain, and the 'great pockes' in England; or it was borrowed from a neighbour, as 'grandgore' in Scotland from 'la grande vérole' in France. The overlapping of older and new terminology in Scotland is illustrated by two maledictions of that time; one was 'leper whore' and the other was 'grandgory leper'.

The expression 'French disease' (morbus gallicus) probably arose from the fact that southern France was the region where the 'new disease' was first noticed, in the second half of the fifteenth century and first distinguished from the 'old leprosy'. Parenthetically, the name syphilis was not generally adopted by the medical profession until the nineteenth century.

The use of mercury in the treatment of ancient 'leprosy' probably came from the Far East to the Middle East, and was then brought to Europe by 'lepers' returning from the Crusades. It was used as inunction ('Saracen ointment') or it was volatilized and inhaled. The intense salivation and the loosening of the teeth were well known and indeed even favourably regarded; but the dangers of mercury poisoning were not realized. Some patients (the true lepers) got no benefit from mercury; the luetics found it good. Since the correct dosage was not known and fatal doses were sometimes given, the ensuing deaths added to the fear of the 'new disease' and gave mercury a poor reputation.

Several decades of diagnostic confusion and popular apprehension elapsed before circumstance permitted lues to assume its true character. When people later looked back on those years of diagnostic chaos, it seemed to them that they had passed through an epidemic which was happily soon over. Subsequent medical writers uncritically accepted this erroneous conception of an epidemic, thus leading to a misinterpretation, causing an egregious misapprehension which still persists.

Meantime what of true leprosy, up to this time the inconspicuous partner in the old 'leprosy syndrome'? Its outlines remained vague even after mercury became the therapeutic test for lues. Finally, in the eighteenth and nineteenth centuries, physicians described it more precisely; in 1873 Hansen of Norway discovered the mycobacterium. Thus the tangled skein of old 'leprosy' was unravelled completely, revealing its two constituents, treponematosis and Hansen's disease.

\section{The significance of Cresseid}

If the astrology and mythology and the aesthetics and morals are set aside, the Testament is essentially the story of a prostitute who acquired venereal syphilis. It is remarkable that Cresseid's case-history, though it has been lying in medical oblivion for five centuries, is as authentic and fresh today as the latest VD statistic. The poet described the features of her case so clearly that even without a positive serological test, the modern diagnosis would have to be syphilis. It is therefore no longer possible to assert, as some do, that there is no record of a clinical case of venereal syphilis in pre-Columbian Europe.

There is ample internal evidence that the poem belongs to the fifteenth century, a product of the poet's mature years but not of his old age. Henryson speaks out of his experience, displaying wide knowledge of his own land and deep sympathy for the human 
condition. He tells the story on two levels. Superficially, it is an ancient tale of thwarted love and sad degradation. On a deeper level, giving it a peculiar significance for the history of syphilis, it concerns itself with the love life of a currently contemporary character, her folly and her end. Few Scottish readers could fail to identify with the story; few would be able to say they had not known of a 'Cresseid' in their time.

As to the approximate date of the poem, there is impressive evidence in the extant Myll manuscript which indicates that it was current before July 10, 1492, three weeks before Columbus sailed on his first voyage. Thus to establish the pre-Columbian date of Cresseid's syphilis is important because a fallacy and a misinterpretation have combined to confuse this period in the history of syphilis.

\section{THE FALLACY}

Some 35 years after Columbus returned in 1493, it was suggested that he might have brought lues from the New World. This idea was not advanced in the explorer's lifetime and subsequently had only a tenuous hold until it came into vogue in the twentieth century (Hudson, 1968). An elaborate story was created to support the 'Columbian theory', but it has since proved to be false in all details.* Thus was launched the fallacy of post hoc ergo propter hoc. It is now widely acknowledged that treponematosis was present on all the continents long before 1493.

\section{THE MISINTERPRETATION}

Around 1500, word of a 'new disease' spread through Europe so rapidly that such metaphors as whirlwind and wildfire were used to describe it. Since not many years had elapsed since the last decimation by the Black Death (bubonic plague), preventive measures were instituted, fatal cases of undiagnosed illnesses of all kinds were attributed to the 'new disease', and people thought they were in the grip of another epidemic. Although this epidemic proved to be a supposition and not a fact, subsequent medical writers have persisted in the use of that term. It turned out that the disease of 1500 and after was spreading rapidly only in the sense that it was being recognized more widely and rapidly. Syphilis was rising to the surface of popular consciousness out of

\footnotetext{
^The crews of the Nina and Pinta were not sick; the ships did not sail to Barcelona; the sailors therefore did not infect the whores of the waterfront; Charles' army had no Spanish contingent; there was no siege of Naples, nor is there any reference in Neapolitan archives to an 'epidemic' of any kind; the army that was supposed to 'scatter' the 'new disease' did not get home in time, for lues had already been reognized in many countries; Columbus did not have syphilis and did not die of tertiary complications.
}

the venereal, congenital, and tertiary conditions of mediaeval 'leprosy'.

In a few decades the disease was said to be 'milder'; this was because diagnosis had improved and mercury had been accorded its proper role in treatment. People realized that this was an old and familiar disease, only new in name; the preventive measures were discarded and popular apprehension diminished. The so-called 'epidemic' was over, in fact, except in the writings of medical historians.

Having converted the popular supposition-the alleged epidemic -into a historical episode, medical writers had the further task of explaining a point which epidemiologists have always found puzzling, viz. how did a person-to-person disease like syphilis suddenly become pandemic as if conveyed by fomites, air, or water? To meet this erroneously conceived dilemma, subsequent writers added the notion of a mutation into a 'venereal treponeme' or postulated a sudden increase in the treponeme's 'virulence'. Some said that since syphilis was so virulent among Europeans, it must have come from a foreign source; others that it was brought from the New World, hence its virulence.

This Janus argument thus linked the fallacy and the misinterpretation. In the orthodox view, the 'imported disease' caused the 'epidemic', and the 'epidemic' marked year one in the history of European syphilis. Virulence, mutation, epidemic, and the legend of Columbus are in fact straw men propped up against each other for mutual support-theories advanced to 'explain' what was actually a misapprehension. There are signs that the 'Columbus theory' is being widely discredited; perhaps the 'epidemic theory' will eventually follow suit.

Denton Fox, the foremost modern authority on Robert Henryson, wrote in 1968:

\footnotetext{
"Some scholars believe that syphilis was indigenous in Europe before Columbus; they argue that mediaeval writers, when they discuss leprosy that could be transmitted venereally, are really talking about syphilis. But whatever the merits of this view (and there seems to be very little evidence to support it), it is at least clear that a sudden and terrifying epidemic of syphilis swept Europe in the last years of the fifteenth century, after the Testament was written" (Fox, 1968, p. 35).
}

Since Fox's medical consultants have misled him as to pre-Columbian syphilis and the alleged 'epidemic' in Europe, his conclusion that Cresseid's disease could not have been syphilis is therefore incorrect. However, he is undoubtedly correct in affirming unequivocally that the Testament was written well before 1500 .

The significance of the Testament is that it was 
written about a case of venereal syphilis before 1492, a fact from which two deductions can be drawn:

(a) The Testament furnishes solid support for the view that syphilis in Europe ante-dated Columbus and that the history of syphilis in Europe therefore had no relation to the discovery of the New World;

(b) Since the story of an imported 'new disease' had no foundation, but merely signalled the recognition of an old one, the 'epidemic', that started as a popular supposition and ended as a historical misapprehension, had no basis in fact.

In conclusion, this study of Henryson's Cresseid contributes to the identification of a fallacy and a misinterpretation in recorded medical history, two errors that each medical generation has passed on to the next, reflecting a lack of critical appraisal and the neglect of non-medical literature.

\section{Summary}

The Testament of Cresseid, by the Scottish poet Robert Henryson (?1440-?1500), includes an account of an undoubted case of sexually acquired syphilis; the original manuscript is lost, but there is contemporary evidence that the poem was in circulation in 1492 , before the voyage of Columbus. This further evidence of pre-Columbian venereal syphilis and the confusion between syphilis and leprosy are discussed in detail.

\section{Acknowledgements}

My thanks are due to Prof. Dr. Wm. Møller-Christensen for a copy of Dr. Andersen's monograph, a valuable source of information about ancient and mediaeval 'leprosy'. I have made constant use of Prof. Denton Fox's book, drawing freely from introduction, text, and notes, with his kind permission. Although I must absolve him from any responsibility for my comments and conclusions, I am indebted to his book for helpful information and insights.

\section{Sources and References}

ANDERSEN, J. G. (1969) 'Studies in the Mediaeval Diagnosis of Leprosy in Denmark. An Osteoarchaeological, Historical and Clinical Study'. Dan. Med. Bull., 16, Suppl. 9

Craigie, W. A. (ed.) (1923-25) 'The Asloan Manuscript: A Miscellany in Prose and Verse written by John Asloan in the Reign of James V', 2 vols. Scottish Text Society, New Series, Nos. 14 and 16

EYRE-TODD, G. (ed.) (1892) 'Robert Henryson' in Mediaeval Scottish Poetry, vol. 2, pp. 77-138. Abbotsford Series of the Scottish Poets. Hodge, Glasgow; Williams and Norgate, London

Fox, D. (ed.) (1968) 'Robert Henryson. Testament of Cresseid'. Nelson's Medieval and Renaissance Library, ed. G. Shepherd. Nelson, London

GREEN, R. (1964) Blackwood's Magazine, 296, 553

Hudson, E. H. (1961a) Arch. intern. Med., 108, 1

- (1961b) Arch. Derm. (Chicago), 84, 545

- (1963) Ann. intern. Med., 58, 1037

- (1965) Amer. Anthropologist, 67, 885

- (1968) Acta tropica, 25, 1

LoNG, E. R. (1964) Int. F. Leprosy, 32, 424

RowLAND, B. (1964) English Language Notes, 1, 175

STEARNS, M. W. (1945) 'Modernization of Robert Henryson's Testament of Cresseid'. Indiana University Publications, Humanities Series No. 11. Bloomington, Indiana 